\title{
Seasonal changes in diversity and abundance of ostracods on four species of intertidal algae with differing structural complexity
}

\author{
Susan L. Hull* \\ University College Scarborough, Filey Road, Scarborough, North Yorkshire YO11 3AZ, United Kingdom
}

\begin{abstract}
Monthly replicate samples of 4 species of common rockpool algae (Ceramium nodulosum, Chondrus crispus, Cladophora rupestris, and Corallina officinalis) were collected in order to investigate the changes in ostracod species abundance, richness and diversity both between the algae species and over a 12 mo period. In order to determine if algal structural complexity had an effect on ostracod abundance and diversity, structural complexity was assessed by counting the number of branches $\mathrm{cm}^{-1}$ frond length. There were significant differences in complexity between the 4 algal species. Ceramium had significantly more branches $\mathrm{cm}^{-1}$ than the remaining 3 algal species, and Cladophora had significantly more branches than Chondrus and Corallina. The abundance and diversity of ostracod assemblages demonstrated pronounced seasonal variation, both within and between the 4 algal species. Ceramium supported a higher abundance, greater species richness and greater diversity of ostracods throughout the year than did Chondrus, which had a less complex structure. The Chondrus samples formed a separate cluster during classification and ordination, reflecting the relative paucity of species and low densities found on that algal species throughout the year. A total of 18 species of ostracod were found on the algae, but only 8 occurred at densities sufficient for determination of their life-cycles. Cythere lutea reproduced in early spring and demonstrated positive covariation in population density with Hirschmannia viridis. H. viridis and Heterocythereis albomaculata demonstrated positive covariation in population density and had similar life-cycles. All 3 species were found at low densities during the winter months, possibly as the result of seasonal migration to sublittoral areas. The remaining 5 species all demonstrated positive covariation in population densities, but reproduced at different times of the year. Semicytherura nigrescens and Xestoleberis aurantia underwent reproduction during summer/autumn. Both Paradoxostoma variabile and $P$. ensiforme appeared to be reproductively active for most of the year, but $P$. hibernicum appeared to be an annual. All 8 species occurred in significantly higher densities on Ceramum than on Chondrus, and during the peak reproductive period as compared to other times. The seasonal changes in ostracod density within the rockpool can be primarily attributed to the reproductive cycles of the component species within the assemblage, and secondarily to the supposed seasonal migration of certain species between intertidal and sublittoral regions.
\end{abstract}

KEY WORDS: Marine ostracods · Assemblage Habitat complexity · Seasonality · Population dynamics

\section{INTRODUCTION}

Ecologists have long recognised the fact that habitat heterogeneity has a marked effect on species diversity and richness, and phytal habitat complexity has been shown to affect both the density and abundance of epifaunal species (for example, Hicks 1980, 1985, Gee \& Warwick 1994, Jarvis \& Seed 1996). The complexity of the phytal habitat is associated with the small-scale

•E-mail: sueh@ucscarb.ac.uk variations in shape, size and texture of the algal species (Gee \& Warwick 1994), and higher population densities often correlate with a more complex physiognomic algal structure (Hicks 1985). This may be the result of increased habitable living space for the organisms (Hicks 1985), increased shelter from predation (Coull \& Wells 1983), protection from desiccation and wave action (Whatley \& Wall 1975), and differential food availability and sediment load (Hicks 1980). However, other factors such as the physiology of the plant (Hagerman 1966), presence of epiphytes (John- 
son \& Scheibling 1987, Jarvis \& Seed 1996), distribution of the algae within microhabitats on the shore (Whatley \& Wall 1975, Preston \& Moore 1989), and plant size (Gunnill 1982) have been shown to affect the community composition of macroalgae.

Many of the previous studies focussed on the composition of phytal macrofaunal assemblages (e.g. Coleman 1940, Dommasnes 1969) and, due to the problems associated with collection, identification and taxonomy, the small, mobile or cryptic species have often been ignored during studies of the dynamics of assemblages (Underwood \& Petraitis 1993). However, more recent investigations have incorporated a study of the dynamics of both macrofauna and meiofauna present on macroalgae (Johnson \& Scheibling 1987, Jarvis \& Seed 1996), and some groups have been studied in detail (e.g. harpacticoid copepods, Hicks 1977, 1980. 1985, and nematodes, Trotter \& Webster 1983, 1984). Members of the Nematoda, Copepoda, Acarina and Ostracoda commonly constitute over $98 \%$ of the phytal meiobenthos. Harpacticoid copepods tend to be the dominant phytal taxa both in terms of species richness and abundance and demonstrate both morphological and behavioural adaptation to life in the phytal habitat (Hicks 1985). Seasonal fluctuations in the composition and abundance of the species within meiofaunal assemblages have been attributed to changes in food availability (Preston \& Moore 1989), the seasonal occurrence of epiphytes (Johnson \& Sheibling 1987) and the seasonal periodicity of the life-cycles of the individual species (Hicks 1985).

The composition of phytal ostracod communities has been described in some detail from South Wales (Whatley \& Wall 1975, Trier 1993), Anglesey (Williams 1969), the Isles of Scilly (Neale 1970), the Bristol Channel (Horne 1982), and Plymouth (Elofson 1940). The relationship between ostracods and algae appears to be complex (Whatley \& Wall 1975), however it was suggested that algae with large flat fronds appear to provide little protection from wave action and desiccation, and therefore support a less diverse community than algae with a more complex structure. Previous ostracod studies have concentrated on the description of the assemblages in space, but have not considered the seasonal dynamics of the assemblages over time, or between different algal species. A notable exception to this is the work of Hagerman, who studied the dynamics of brackish water ostracod assemblages on Corallina officinalis in Norway (Hagerman 1968) and from the green algal belt in the Øresund, Sweden (Hagerman 1966, 1978).

The current study aims to investigate the seasonal dynamics of ostracod assemblages on a micro-scale. Four species of rockpool algae were chosen primarily for their apparent difference in structural complexity and year-round presence in the rockpools in order to determine if ostracod abundance and diversity varied with season and micro-habitat complexity.

\section{METHOD}

Sample collection and identification. In order to investigate the micro-scale dynamics of intertidal ostracod assemblages, 2 replicate samples of 4 species of algae were randomly collected each month at $20 \mathrm{~cm}$ depth from the centre of a large, mid-shore rockpool (length $10 \mathrm{~m}$, width $4.5 \mathrm{~m}$ ) on an exposed shore at Peak Steel, Ravenscar (British National Grid Reference NZ/984021), between March 1995 and March 1996. The 4 species of algae, Cladophora rupestris (L.) Kützing, Corallina officinalis L., Ceramium nodulosum (Lightfoot) Ducluzeau, and Chondrus crispus Stackhouse (hereafter referred to by their genus names only), were chosen because of their apparent difference in frond structural complexity, and also because they were present in the pool throughout the entire year. This enabled seasonal comparisons of ostracod density and diversity to be undertaken between the 4 algal species.

Many different methods have been used to describe the complexity of the structure of different species of algae (Gee \& Warwick 1994). For the purpose of the current investigation a simple estimation of the complexity of the structure of the algal micro-habitats was required. On one occasion, a sub-sample of the 4 algal species was collected, and measurements of frond length and the number of branches were recorded in order to provide an estimation of the degree of branching per unit length for each of the 4 species.

A solution of $4 \%$ formalin in seawater was added to the samples on return to the laboratory. Ostracods were then carefully removed from the algae by repeated washing with seawater through $1 \mathrm{~mm}, 250 \mu \mathrm{m}$ and $65 \mu \mathrm{m}$ sieves. The algae were then checked to ensure that all the ostracods had been removed, prior to being dried and weighed. The ostracods were picked from the sieves and stored in $70 \%$ alcohol until required for analysis. All the individual ostracods collected from each sample were identified and measured. The carapace length of all the individual ostracods was measured using an eye-piece graticule, in order to identify the developmental instars. Identification was performed using both a high-power compound microscope and binocular microscope; the taxonomy is based upon that of Athersuch et al. (1989). Results are expressed as number of ostracods per $15 \mathrm{~g}$ dry weight of Cladophora, Ceramium, and Chondrus, and as $30 \mathrm{~g}$ dry weight of Corallina as corallines are heavier per unit than more delicate species (Hicks 1985). 
Data analysis. Cochran's test (Underwood 1997) was used to test for the homogeneity of variances, and to remove any heterogeneity all ostracod density data were $\log _{10}$-transformed prior to ANOVA (Fowler \& Cohen 1990). All 1-way and 2-factor ANOVA tests were of a fixed, balanced design, therefore Tukey tests were performed to determine the source of the significance between means (Fowler \& Cohen 1990). Oneway ANOVA was used to determine significant differences in ostracod densities either between algal species or over the sampling period. Two-factor ANOVAs were used to examine the significance of the effect of algal species and month over the sampling period. Eight ostracod species occurred in sufficiently high densities throughout the year to enable their lifecycles to be determined and changes in density to be statistically tested using ANOVA. Spearman rank correlation coefficients were calculated in order to investigate possible covariation in density between the 8 species (Ludwig \& Reynolds 1988).

Shannon Wiener diversity $\left(H^{\prime}\right)$, species richness $(S)$ and Evenness $(E)$ were calculated on the pooled samples for each species of algae within each month. As $H^{\prime}$ was normally distributed, ANOVA was used to test for significant differences in diversity between the algal species and over the sampling period within an algal species (Magurran 1989).

A dendrogram from a Bray Curtis similarity matrix was produced using group average clustering on square-root-transformed abundance data using the PRIMER (Plymouth Routines In Multivariate Ecological Research) analysis package. The calculated similarity matrix was also used to produce a 2-dimensional MDS (multi-dimensional scaling) plot. In order to overcome the subjective analysis of the MDS ordination plot, a 2 way ANOSIM was applied to the similarity matrix in order to test the null hypothesis that there was no significant difference in similarity between months for the 4 algal species, or between the 4 algal species (Clark \& Warwick 1994). ANOSIM calculates an overall global rho statistic ( $R$ statistic), which is then compared to the $R$ statistic calculated for all the possible permutations of the replicates. The significance value (given as a percentage) indicates the number of times that a better assemblage pattern was created by random rearrangement of the matrix compared to that of the original data

\section{RESULTS}

\section{Habitat description}

In order to obtain some index of structural complexity, the number of branches $\mathrm{cm}^{-1}$ for the 4 algal species was compared (Table 1). The highest degree of branching was found in Ceramium, which had a significantly higher number of branches $\mathrm{cm}^{-1}$ than the 3 other species. Cladophora had a significantly higher number of branches $\mathrm{cm}^{-1}$ than Chondrus and Corallina. However, there was no significant difference in the number of branches $\mathrm{cm}^{-1}$ between Corallina and Chondrus. Therefore Ceramium presents the most, and Chondrus and Corallina the least, complex habitat structure for algal meiofauna.

\section{Seasonal patterns in density of ostracods}

A total of 18 ostracod species from 6 families were identified from the samples of algae collected over the

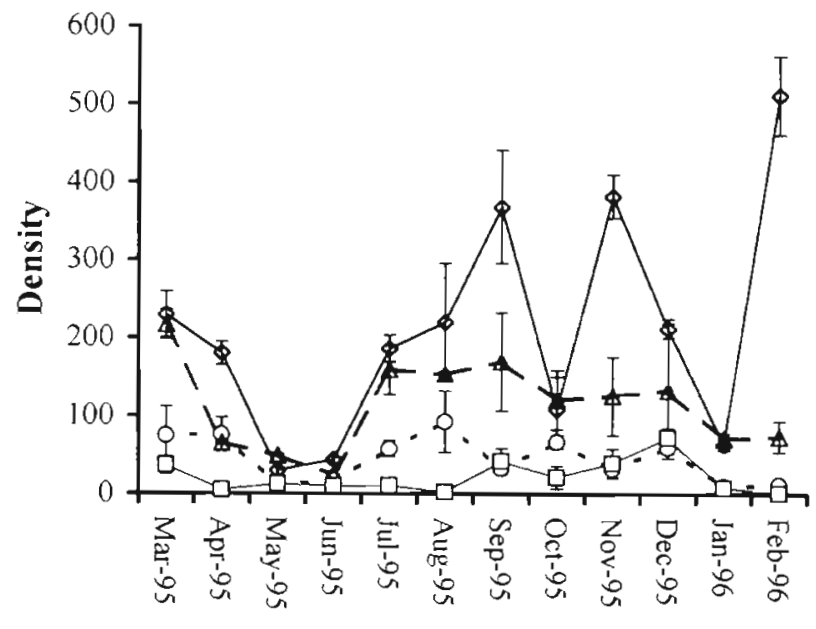

Month

\begin{tabular}{ll}
\hline - O- Corallina & - Ceramium \\
$-\Delta-$ Cladophora & $-\square-$ Chondrus
\end{tabular}

Fig. 1 Changes in ostracod assemblage density ( \pm standard deviation) on 4 rockpool algae (Corallina officinalis, Ceramium nodulosum, Cladophora rupestris, Chondrus crispus) over the 12 mo sampling period

Table 1 One-way ANOVA for number of branches $\mathrm{cm}^{-1}$ for the 4 algal species studied. ANOVA $F_{3,51}=43.14, \mathrm{p}<0.0001$; Tukey $\mathrm{p}=0.05$. Groups with same letter are not significantly different

\begin{tabular}{|lccc|}
\hline Species & $\begin{array}{c}\text { Mean branches } \\
\left(\mathrm{cm}^{-1}\right)\end{array}$ & SD & $\begin{array}{c}\text { Tukey } \\
\text { group }\end{array}$ \\
\hline Ceramium nodulosum & 14.14 & 3.51 & $\mathrm{~A}$ \\
Cladophora rupestris & 10.35 & 4.10 & $\mathrm{~B}$ \\
Corallina officinalis & 3.29 & 1.59 & $\mathrm{C}$ \\
Chondrus crispus & 2.08 & 1.45 & $\mathrm{C}$ \\
\hline
\end{tabular}



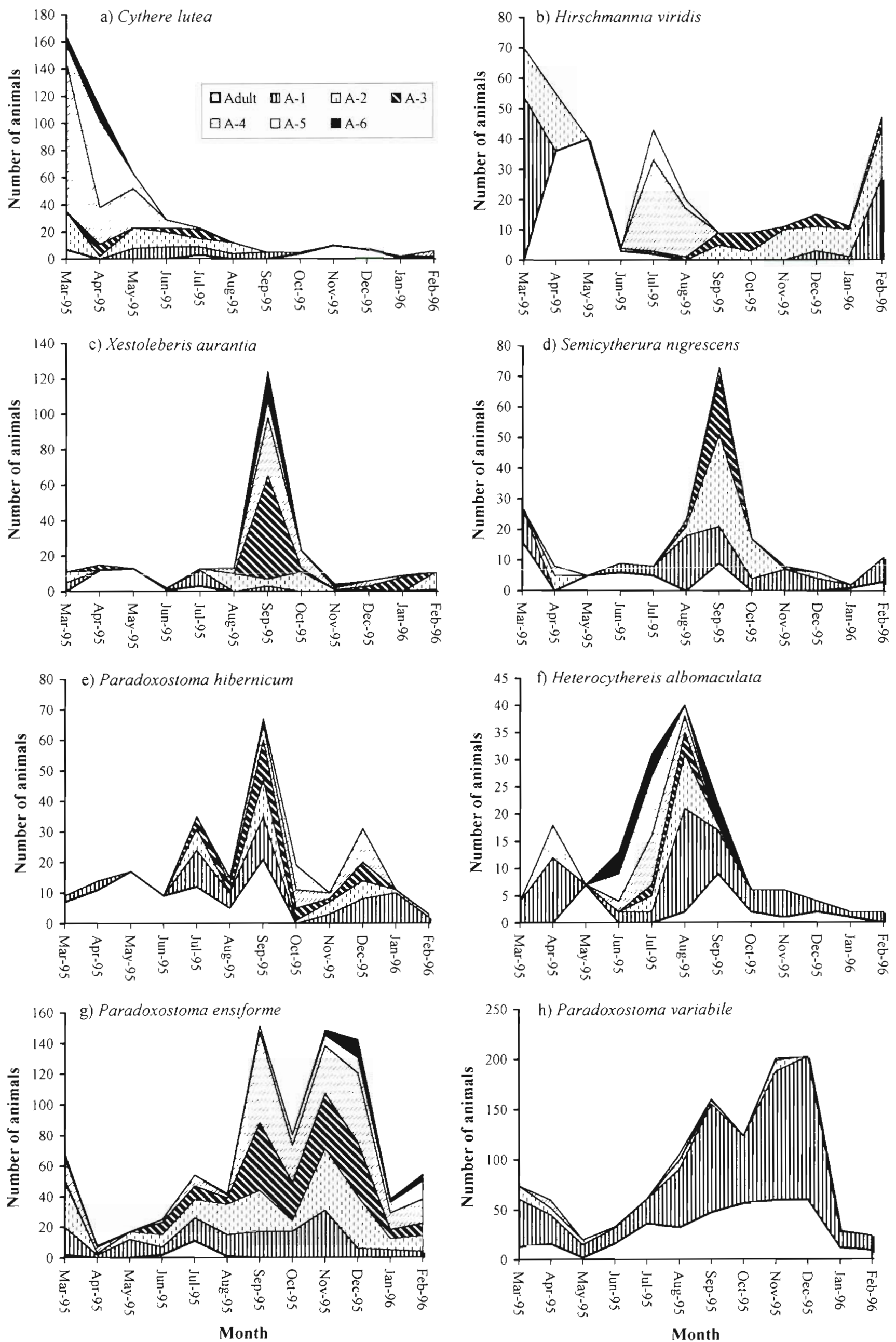
study period (Appendix 1). Fig. 1 illustrates the mean ostracod density on the 4 algal species over the sampling period. There were significant differences in ostracod density both between the weed species and with each month, and the interaction between month and algal species was also significant (2-way ANOVA, $\mathrm{p}<0.0001$ in all cases). Overall, Ceramium (mean ostracod density $=211.3 \pm 149.43$ SD) supported higher ostracod densities than Chondrus (mean $=21.74 \pm$ 23.31), Corallina (mean $=45.24 \pm 33.90$ ) and Cladophora (mean $=113.26 \pm 67.93$ ), whereas Cladophora supported higher densities than Chondrus and Corallina (ANOVA $F_{392}=24.21, p<0.0001$; Tukey $p=0.05$ ).

On Ceramium, ostracod density was significantly higher during February 1996 than throughout the rest of the year except for November and September 1995 (ANOVA $F_{11,12}=14.59, \mathrm{p}<0.0001$; Tukey $\mathrm{p}=0.05$ ). Assemblage density was higher during September than during May, June and October, and the density found in November was higher than that found in June, October and January. However, a different pattern was observed in Chondrus: the ostracod density of the December sample was greater than that of April-August (inclusive), and the density of the February sample was less than that of the January and December samples (ANOVA $F_{11,12}=4.89, p=0.005$; Tukey $\mathrm{p}=0.05$ ). There was no significant difference in ostracod density throughout the year on Cladophora (ANOVA $F_{11,12}=2.26, p=0.088$ ) and, although ANOVA suggested significant density differences for Corallina (ANOVA $F_{11.12}=2.78, \mathrm{p}=0.046$ ), all Tukey comparisons were non-significant.

\section{Changes in population density and ostracod life-cycles}

Eight out of the 18 species recovered from the algae (Cythere lutea, Heterocythereis albomaculata, Hirschmannia viridis, Xestoleberis aurantia, Semicytherura nigrescens, Paradoxostoma ensiforme, P. hibernicum, and $P$. variabile) were found in sufficient numbers to examine changes in their population density both throughout the year and also between the 4 algal species. The remaining species (Paradoxostoma abbreviatum, P. normani, P. robinhoodi, P. bradyi, P. nealei, Hemicytherura cellulosa, Palmoconcha laevata, Cytherois fischeri, Semicytherura sella, Xestoleberis depressal occurred at low densities or were only found intermittently and therefore are excluded from this part of the analysis. There was no significant difference in the density of the 8 individual ostracod species between the algal replicates collected within each month (for all species ANOVA $p>0.1$ ). All 8 ostracod species showed significant changes in density both between the algal species and month, with the interaction between algal species and month also being significant in all cases (2-way ANOVA $\mathrm{p}<0.001$ in all cases). Overall, Ceramium supported higher population densities of $C$. lutea, $P$. variabile and $H$. albomaculata than did Chondrus (ANOVA; Tukey $\mathrm{p}=0.05$ ) and $P$. ensiforme, $X$. aurantia and $S$. nigrescens occurred in significantly higher densities on both Ceramium and Cladophora than on Corallina and Chondrus (ANOVA; Tukey $\mathrm{p}=0.05$ ). Ceramium also supported significantly higher population densities of both $P$. hibernicum and $H$. viridis (ANOVA; Tukey $\mathrm{p}=0.05$ ) than did Chondrus, Cladophora and Corallina.

All the algal samples were pooled for each month to provide sufficient numbers to determine the life-cycle of the 8 ostracod species within the large rockpool. Fig. 2a illustrates the life-cycle of Cythere lutea. Reproduction occurred in early spring, resulting in peak population densities during March-April consisting mainly of A-4 and A-5 instars. These matured throughout the summer months and the population appeared to overwinter at low densities as adults or A1 and A-2 instars. The pool population density was significantly higher in March than in all other months except April (ANOVA $F_{11,84}=4.01, \mathrm{p}<0.0001$; Tukey $p=0.05$ ). Hirschmannia viridis (Fig. $2 \mathrm{~b}$ ) moulted to an adult in spring when reproduction took place (March to May), resulting in the appearance of juveniles within the population during June-September. These developed as far as the A-1 to A-3 instar and overwintered in these stages, moulting to adults in the following spring. $H$. viridis demonstrated significant differences in population density throughout the year (ANOVA $F_{11,84}=1.98, \mathrm{p}=0.041$ ) but the Tukey comparisons between the months were not significant. Xestoleberis aurantia (Fig. 2C) showed a similar pattern, overwintering in the A-1 and A-2 instar and moulting to the adult stage during late spring. Females were observed to be carrying eggs from May to September, and juveniles were present in high numbers during August to November. The density of the population was significantly higher during September than throughout the rest of the sampling period (ANOVA $F_{11,84}=3.69, \mathrm{p}<0.0001$; Tukey $\left.\mathrm{p}=0.05\right)$. A similar lifecycle pattern was shown by $X$. depressa, although this

Fig. 2. Life-cycles of the 8 commonest intertidal ostracod species, reflecting changes in population density and the appearance of different instars within each population. The instars are labelled in descending order of size (A-1, A-2, etc.). A-1 is a pre-adult stage (after Athersuch et al. 1989) 
species was only found in low densities. In Semicytherura nigrescens (Fig. 2d), peak population densities occurred during July-November due to the appearance of juveniles, probably after reproduction during the months of June and July. The S. nigrescens population appeared to overwinter either as adults or in the A-1 instar stage, which moulted to the adult stage in spring. Despite a reproductive peak during September, there was no significant difference in population density throughout the months sampled (ANOVA $F_{11,84}=1.69, \mathrm{p}=0.088$ ). Paradoxostoma hibernicum (Fig. 2e) predominantly occurred as adults or late instars during March-June. Juveniles appeared in the population during June-August, but maximum population densities were reached during September-October. The population overwintered as juveniles or late instars, moulting to the adult stage in spring. The population density of $P$. hibernicum was significantly higher in September than in March, April, June, October, November and January (ANOVA $F_{11,84}$ $=2.20, p=0.022$; Tukey $\mathrm{p}=0.05$ ). The peak population density of Heterocythereis albomaculata (Fig. 2f) occurred during June-October when the population was dominated by juvenile instars. The species overwintered as either adults or A-1 instars. It is possible that reproduction also occurred in late winter as A-5 instars were also found during March-May. The density of the $H$. albomaculata population was significantly higher in August than in December and January (ANOVA $F_{11.84}=2.48, \mathrm{p}=0.009$; Tukey $\mathrm{p}=0.05$ ). In both $P$. ensiforme (Fig. $2 \mathrm{~g}$ ) and $P$. variabile (Fig. $2 \mathrm{~h}$ ) maximum population densities occurred during September-January. However, few juveniles of $P$. variabile were found during the sampling period, and the population appeared to consist mainly of A-1 instars and adults throughout the entire year. During November the population density of $P$. variabile was significantly higher than that found during March-June inclusive, January and February; density in October was higher than in May, and during December densities were higher than those found in May and June (ANOVA $F_{11.84}=4.72, p<0.0001$; Tukey $\mathrm{p}=0.05$ ). Juveniles of $P$. ensiforme were present at low densities throughout the entire year, but peak densities occurred during September-December when no adults were present in the population. P. ensiforme occurred in significantly higher densities during November than April-June inclusive (ANOVA $F_{11.84}=$ $2.82, \mathrm{p}=0.003$; Tukey $\mathrm{p}=0.05$ ). In a related species, $P$. normani, juveniles were only found during October-December, and only adults were occasionally found in other samples.

As there was no significant difference in species density between the replicate samples, the monthly replicate data for each algal species was pooled and used to determine if there was any interspecific covariation between the densities of the 8 ostracod species using the Spearman rank correlation coefficient $\left(r_{s}\right)$ The density of $C y$ there lutea demonstrated significant positive covariation only with Hirschmannia viridis, and $H$. viridis demonstrated a significant positive covariation with Heterocythereis albomaculata $\left(\mathrm{r}_{\mathrm{s}}, \mathrm{p}<\right.$ 0.001 ). The remaining 6 species (Paradoxostoma variabile, P. ensiforme, P. hibernicum, Xestoleberis aurantia and $H$. albomaculata) all demonstrated positive covariation $\left(r_{s}, p<0.05\right.$ in all cases $)$.

\section{Changes in diversity and classification of the ostracod assemblages}

Fig. 3 illustrates the diversity, richness and evenness of the ostracod assemblages on the 4 species of algae throughout the year. There was a significant difference in Shannon Wiener $H^{\prime}$ both between algal species and months within each algal species (2-way ANOVA $p<$ 0.001 in all cases). When values for the entire year were compared, Chondrus had an overall significantly lower diversity than Ceramium, Corallina and Cladophora (Fig. 3a: ANOVA $F_{3,92}=6.34, p=0.001$; Tukey $p=0.05$ ), but there was no significant difference in ostracod assemblage diversity between the 3 other algal species.

Cladophora showed no monthly significant differences in diversity (ANOVA $F_{11,12}=2.36, \mathrm{p}=0.077$ ), but the remaining 3 species of algae demonstrated significant differences in ostracod diversity with season. For Ceramium, the October sample had a significantly lower diversity than March-September inclusive, and the February sample had a significantly higher diversity than October, November and January (ANOVA $F_{11,12}=7.00, \mathrm{p}=0.001$; Tukey $\mathrm{p}=0.05$ ). There were less marked differences observed in Chondrus, where the April sample had a significantly lower diversity than that of July (ANOVA $F_{11,12}=3.21, p=0.028$; Tukey $p=$ 0.05 ). For Corallina, the April and October samples had a significantly lower diversity than March and June-August inclusive, and the July and August samples had a significantly higher diversity than those from January and February (ANOVA $F_{11,12}=7.93, \mathrm{p}=$ 0.001 ; Tukey $p=0.05$ ). In terms of overall species richness, Chondrus (median number of species $=6$ ) supported significantly fewer species than did Ceramium (median $=9$ ), Cladophora and Corallina (median for both species $=8$ ) (Kruskal Wallis test, $H=13.58$ adjusted for ties, df $=3, p=0.004$; Fig. 3b). Evenness remained high throughout the summer months in all 4 species, but was low in autumn and early winter, reflecting the dominance of the assemblage by Paradoxostoma variabile and $P$. ensiforme (Fig. $3 \mathrm{C}$ ). 

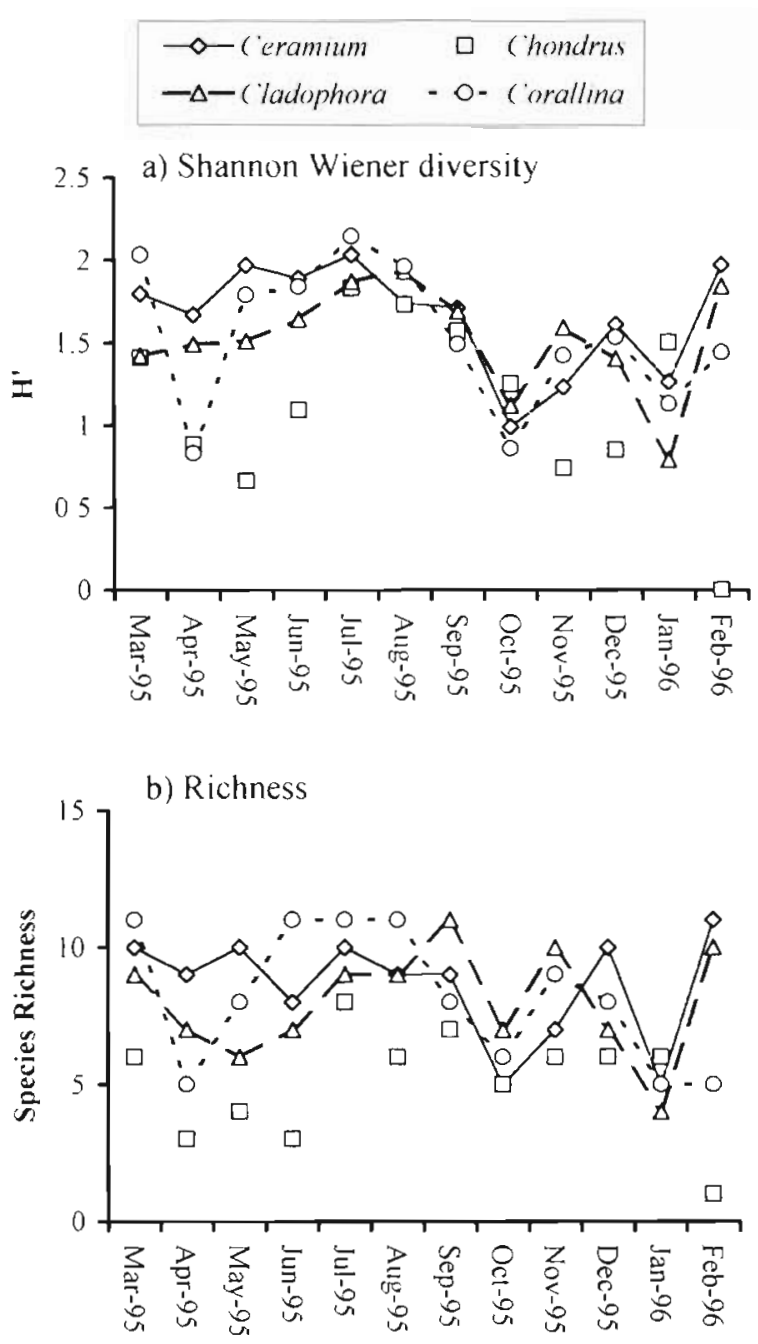

c) Evenness

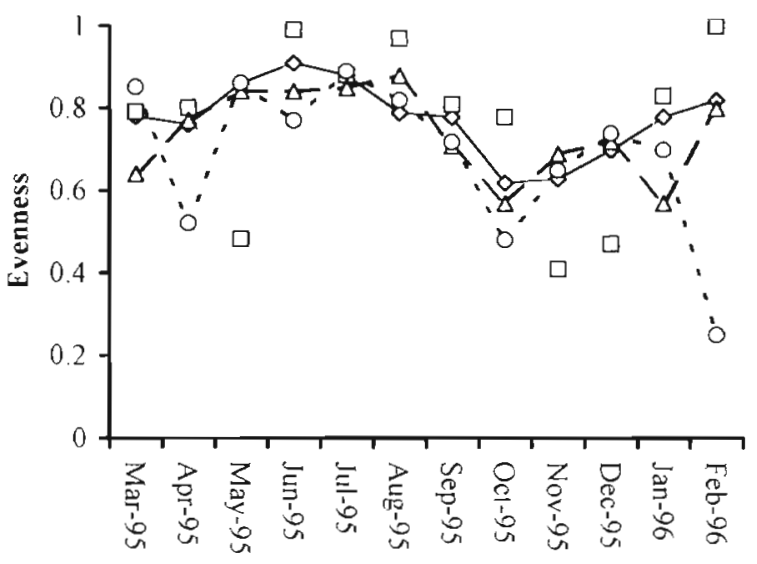

Month

Fig. 3. Changes in ostracod Shannon Wiener diversity, species richness and evenness on 4 species of rockpool algae (Corallina officinalis, Ceramium nodulosum, Cladophora rupestris, Chondrus crispus) over a 12 mo period
The dendrogram produced from the Bray-Curtis similarity coefficients showed 5 main clusters (Fig. 4). Cluster A had only $30 \%$ similarity to the rest of the clusters and consisted entirely of the 12 Chondrus samples that clustered together at approximately 56\% similarity. The remaining 3 clusters were formed at approximately $48 \%$ similarity. Cluster B (at approximately $50 \%$ similarity) contained primarily spring and summer samples from the remaining 3 species of algae. Within cluster C (approximately $62 \%$ similarity) the samples from May clustered together at approximately $65 \%$ similarity. Autumn and early winter (August-December) samples formed cluster D at approximately $58 \%$ similarity, and cluster D showed approximately $53 \%$ similarity to clusters $\mathrm{B}$ and C. Cluster $\mathrm{E}$ at $61 \%$ similarity contained samples collected from January and February and showed approximately $48 \%$ similarity to clusters B, C and D.

The MDS ordination plot (Fig. 5) showed a similar pattern. All the Chondrus samples form a discrete cluster, and the samples from the remaining 3 species of algae could be attributed to clusters of spring/summer, autumn/winter and samples taken from January/February 1996. Two-way ANOSIM indicated that there was no significant difference in similarity between the months sampled (global $\mathrm{R}=0.094$, significant level $=$ $6.9 \%, 346$ out of 5000 permutations produced values greater than or equal to calculated global R). However, there was a significant difference in similarity between the 4 algal species (global $R=0.662$, significant level $=$ $0.0 \%, 0$ out of 5000 permutations produced values greater than or equal to calculated global R).

\section{DISCUSSION}

Intertidal ostracod phytal assemblages show marked seasonal changes in species composition and density, and there is strong evidence that the degree of substrate complexity affects both the abundance and diversity of the assemblage in both space and time. Ceramium had the most complex frond structure and supported significantly higher densities of ostracods than the remaining 3 algal species. Cladophora was intermediate in frond complexity and supported significantly higher densities than Corallina and Chondrus. Ostracod density, richness and diversity were found to be significantly lower on Chondrus than Ceramium throughout the entire year, thus the alga with the least complex frond structure supported fewer individuals and a less diverse ostracod assemblage. Algal meiofauna usually achieve highest densities on sheltered shore algae with complex frond structure and lowest densities on exposed shore algae with a less complex structure (Hicks 1985). Using fractals as a method for 


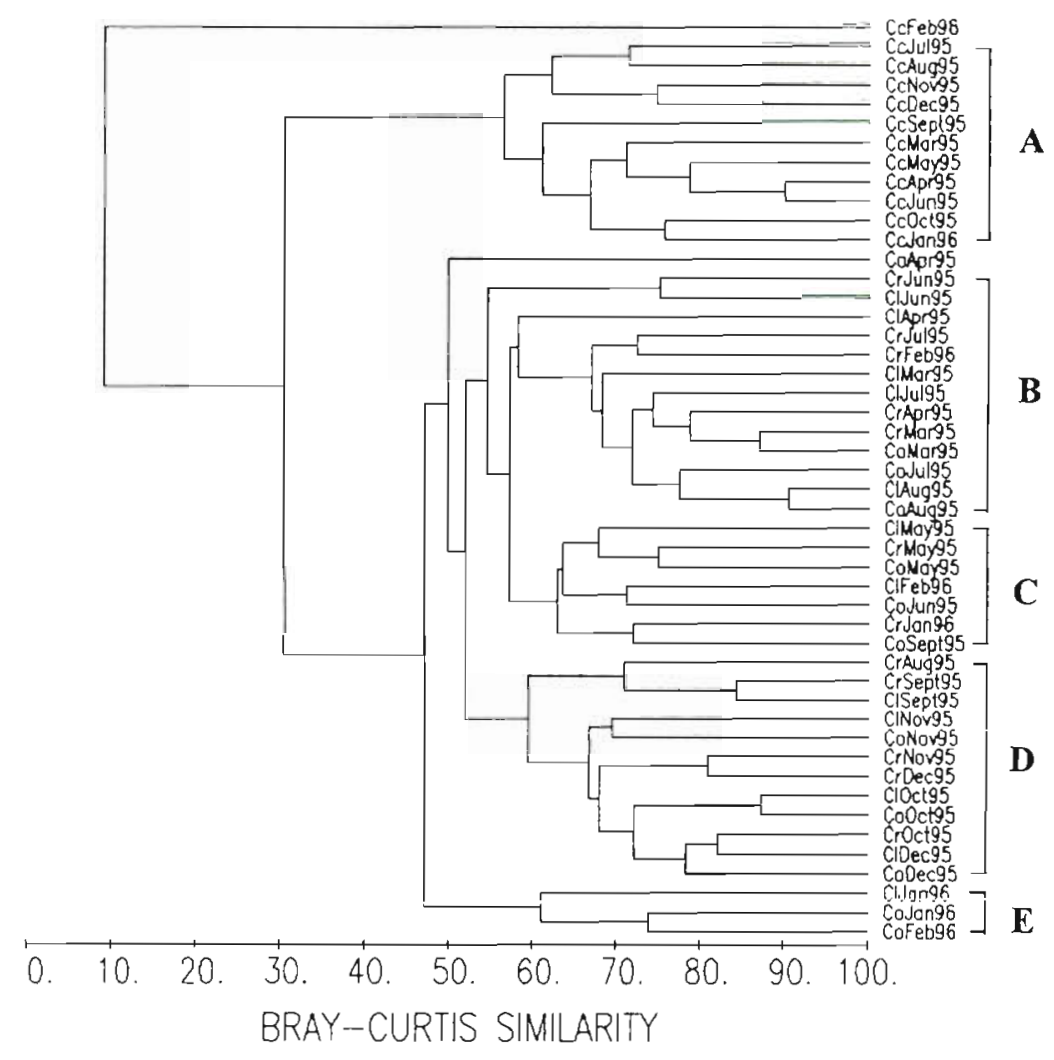

Fig. 4. Dendrogram of Bray Curtis similarity coefficients for pooled monthly samples of 4 species of algae collected over a 12 mo period. (Key: Co $=$ Corallina officinalis samples, $\mathrm{Cc}=$ Chondrus crispus, $\mathrm{Cl}=$ Cladophora rupestris, $\mathrm{Cr}=$ Ceramium nodulosum, followed by first 3 or 4 letters of month and year of collection)

describing algal complexity, Gee \& Warwick (1994) noted that increased algal complexity was accompanied by an increased diversity of both meiofauna and macrofauna. Whatley \& Wall (1975) found higher densities of ostracods on algae with a more complex frond structure, such as Cladophora, and suggested that algae with large, flat fronds would provide little protection from desiccation and wave action. Johnson \& Scheibling (1987) found no significant changes in ostracod density either between months or between Fucus vesiculosus and Ascophyllum nodosum, however ostracod densities are known to be low on these macroalgal species (Whatley \& Wall 1975). Jarvis \& Seed (1996) noted that ostracods demonstrated significant temporal changes on Pilayella littoralis (an epiphyte of Ascophyllum nodosum) which they attributed in the main to the life-cycle of Hirshmannia viridis. Another epiphytic species with a less complex frond structure, Polysiphonia lanosa, supported lower meiofaunal densities and showed little temporal variation.

Fish have been shown to feed on ostracods. Maximum population densities of juveniles of the mullid fish Upeneichthys porosus, which predominantly fed on ostracods, coincided with minimum coralline turf invertebrate densities. However, field-based fish exclusion experiments failed to distinguish predation effects from the temporal dynamics of the ostracod prey (Choat \& Kingett 1982). Algal complexity has been shown to have an effect on the success of fish predators whilst they were preying on copepods (Coull \& Wells 1983). Despite this, fish predation is thought to have little effect on the permanent meiofauna and becomes important only when fish are trapped for long periods of time in tidal pools (Gibbons 1988). Besides complexity, the rigidity of the algal fronds may also have an effect upon predator surcess. The fronds of Corallina are rigid, and the blenny Helcogramma medium (Günther) was observed to wait until prey items were on the edge of the fronds rather than push the fronds aside (Coull \& Wells 1983). Therefore, algae with a complex frond structure or with rigid fronds may provide a refuge from fish predation in tidal pools, but the effects of predation on the ostracod assemblages may be minimal.

The observed marked fluctuations of ostracod assemblage density can be primarily explained by 2 factors - the reproduction of the component species creating maximum densities during certain months, and the supposed migration of the species to different tidal heights

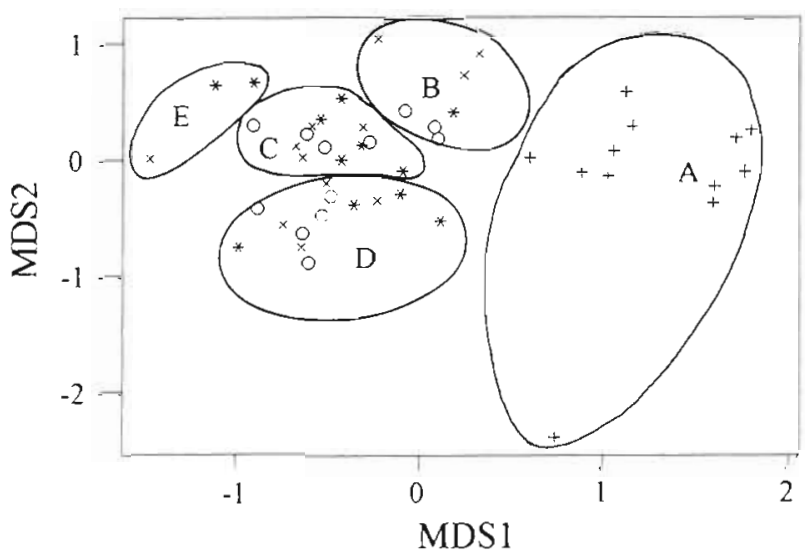

Fig. 5. MDS plot generated from similanty matrix for pooled monthly samples of 4 species of algae collected over a 12 mo period. (Key: $\mathrm{O}=$ Ceramium nodulosum samples, $+=$ Chondrus crispus, $x=$ Cladophora rupestris, $*=$ Corallina officinalis] 
at different times of the year. Cythere lutea and Hirschmannia viridis demonstrated positive covariation in population density and an annual life-cycle. $H$. viridis overwintered as a late instar and moulted to an adult in spring. Hagerman (1969) demonstrated that copulation takes place at temperatures greater than $6^{\circ} \mathrm{C}$. Peak population densities were found in early spring and June due to the appearance of juveniles. However, $C$. lutea appeared to reproduce during early spring, and juveniles were present during MarchJune, after which the adults and late instars were found at low population densities throughout the rest of the year. Hagerman (1969) suggested that the low densities of $H$. viridis observed during the winter months were the result of seasonal migration to sublittoral areas, and Whatley \& Wall (1975) suggested that C. Lutea also overwintered sublittorally. Heterocythereis albomaculata showed positive covariation in population density with $H$. viridis, and a similar pattern of reproduction. As low densities of $H$. albomaculata were found during the winter months this species may also overwinter sublittorally.

Other species appeared to reproduce during late summer and early autumn. The rate of development of the instars of both Semicytherura nigrescens and Xestoleberis aurantia has been shown to be temperature dependent, and at temperatures of $10^{\circ} \mathrm{C}$ the larvae of $X$. aurantia die after hatching, and $S$. nigrescens takes $60 \mathrm{~d}$ to develop to maturity (Hagerman 1978). S. nigrescens reached maximum population densities in August-September, when juveniles appeared in the population, but was found at low densities throughout the rest of the year. Preston \& Moore (1989) found a similar life-cycle pattern on Cladophora albida in Scotland. However, S. nigrescens dominated an assemblage throughout the entire year on Corallina in western Norway (Hagerman 1968), and green algal belt brackish water populations in Sweden produced 4 to 5 generations per year, depending upon temperature (Hagerman 1978). $X$. aurantia demonstrated positive covariation in population density with $S$. nigrescens, with peak population densities occurring during August-September due to the appearance of juveniles in the population. A similar pattern was noted in brackish water conditions in Sweden. The juveniles of this species hatch as A-7 instars, and each female can produce between 25 and 30 eggs (Hagerman 1978).

The genus Paradoxostoma occurred at relatively low densities during spring and early summer but dominated the assemblage of all 4 algal species during late autumn and winter. $P$. hibernicum appeared to have an annual life-cycle, reproducing during late spring and overwintering as A1 to A3 instars which moulted to adults during spring. Both $P$. ensiforme and $P$. variabile appeared to reproduce throughout the entire year, but population densities reached a maximum during autumn and winter months. $P$. variabile is thought to have an 18 mo life-cycle (Athersuch et al. 1989), thus the observed pattern could be the result of differential maturity of overlapping generations within the species or the slower development due to the cooler temperatures during the winter months. The changes in population density could also be explained by seasonal migration of $P$. variabile and $P$. ensiforme from the sublittoral during summer months to the intertidal during winter.

Of the 18 species found on Corallina at Ravenscar, 8 can be regarded as permanent in habitants of the algae as compared with the 4 species in Norway (Hagerman 1968). The remaining species were only found occasionally or occurred at low densities. Whatley \& Wall (1975) found 7 species at low densities on Chondrus, compared with 14 species in high densities during spring and summer on Cladophora. In the current study, the Chondrus assemblage was significantly lower in diversity and richness than the Ceramium assemblage, and ordination revealed that the Chondrus samples formed a separate cluster from the other algal species. All 8 species investigated in the current study occurred in significantly higher densities on Ceramium than Chondrus, and a further 4 species, (Hemicytherura cellulosa, Xestoleberis aurantia, Cytherois fischeri, Paradoxostoma abbreviatum, $P$. normani) were never found on Chondrus, but did occur on the other species of algae. Meiofaunal densities have been shown to vary with the seasonal occurrence of diatoms and blue-green algae (Preston \& Moore 1989) and also algal sediment content (Hicks 1980, 1985). The less complex frond structure of Chondrus would trap less sediment than the other algal species and provide little protection from predation and therefore support few ostracods. The Paradoxostoma species were the dominant species found upon Chondrus throughout the entire year, with a peak in density occurring during the winter months. The other species were only found occasionally. The Paradoxostomatidae have styliform mandibles and are thought by some workers to feed on plant sap (Elofson 1940), and thus would be able to feed on Chondrus, unlike the other species which are thought to feed on epiphytic diatoms and bacteria. However, their frequent association with impenetrable coralline algae suggests that they feed on epiphytic bacteria and diatoms rather than plant sap (Whatley \& Wall 1975), and therefore there must be other factors besides food availability that control the occurrence of the paradoxostomatids on the different algal species.

The current study has revealed a dynamic assemblage that demonstrates marked seasonal change in 
species composition between 4 species of algae with differential complexity in frond structure. The changes in ostracod density can primarily be explained by the seasonal changes in population density associated with the reproduction of the component species and the migration of some species between the intertidal and sublittoral at different times of the year.

Acknowledgements. The author thanks the Research and Postgraduate School at University College Scarborough for providing funding for the project, and also 4 anonymous referees for comments that improved an earlier draft of the manuscript.

Appendix 1. Pooled monthly replicate ostracod numbers found on 4 species of rockpool algae over 12 mo

\begin{tabular}{|c|c|c|c|c|c|c|c|c|c|c|c|c|c|}
\hline Species & & Mar & Apr & May & Jun & $\mathrm{Ju}]$ & Aug & Sep & $\mathrm{Oct}$ & Nov & Dec & Jan & $\mathrm{Feb}$ \\
\hline \multicolumn{14}{|c|}{ Ceramium nodulosum ( $2 \times 15 \mathrm{~g}$ dry weight each month) } \\
\hline \multicolumn{14}{|c|}{ Family Cytheridae } \\
\hline Cythere lutea & (O.F. Müller, 1785) & 163 & 95 & 17 & 16 & 45 & - & - & - & 17 & 8 & 4 & 172 \\
\hline \multicolumn{14}{|l|}{ Family Cytherurinae } \\
\hline Hemicytherura cellulosa & (Norman, 1865) & - & - & - & - & 11 & 5 & - & - & - & - & - & - \\
\hline Semicytherura nigrescens & (Baird, 1938) & 28 & 10 & 1 & - & 13 & 55 & 76 & - & 39 & 15 & - & 9 \\
\hline Semicytherura sella & (Sars, 1866) & 19 & - & - & - & - & - & - & - & - & - & - & - \\
\hline \multicolumn{14}{|c|}{ Family Hemicytheridae } \\
\hline Heterocytheress albomaculata & (Baurd, 1838) & 4 & 10 & 4 & 4 & 33 & - & - & - & - & - & - & - \\
\hline \multicolumn{14}{|c|}{ Family Loxoconchidae } \\
\hline Hirschmannia viridis & (O.F. Müller, 1785) & 96 & 120 & 7 & - & 103 & 15 & 6 & - & - & 1.0 & 30 & 143 \\
\hline Palmoconcha laevata & (Norman, 1865) & - & - & - & - & - & - & - & - & 1 & - & - & - \\
\hline \multicolumn{14}{|l|}{ Family Xestoleberidae } \\
\hline Xestoleberis depressa & Sars, 1866 & - & - & 4 & 16 & 11 & 133 & - & - & - & - & - & - \\
\hline Xestoleberis aurantia & (Baird, 1838) & 7 & 5 & 2 & 16 & 64 & - & 94 & - & 22 & 21 & 4 & 6 \\
\hline \multicolumn{14}{|l|}{ Family Paradoxostomatidae } \\
\hline Paradoxostoma abbreviatum & Sars, 1866 & - & - & - & - & - & 5 & 2 & - & - & - & - & - \\
\hline Paradoxostoma bradyi & Sars, 1928 & - & 5 & - & - & - & - & 2 & 3 & - & - & - & - \\
\hline Paradoxostoma ensiforme & Brady, 1868 & 46 & 50 & 10 & 4 & - & 40 & 75 & 99 & 308 & 129 & 36 & 96 \\
\hline Paradoxostoma hibernjcum & Brady, 1868 & - & - & 8 & 2 & 48 & 49 & 47 & 6 & - & 8 & - & 17 \\
\hline Paradoxostoma normani & Brady, 1868 & 15 & 5 & - & 15 & 10 & 9 & 17 & 6 & 6 & 14 & - & 23 \\
\hline Paradoxostoma robinhoodi & Horne \& Whittaker, 1985 & 56 & - & 2 & - & - & - & - & - & - & - & - & 23 \\
\hline Paradoxostoma variabile & (Baird, 1835) & 72 & 60 & 7 & 15 & 34 & 129 & 65 & 101 & 339 & 177 & 55 & 71 \\
\hline Cytherois fischeri & (Sars, 1866) & - & - & - & - & - & - & - & - & - & 6 & - & \\
\hline \multicolumn{14}{|c|}{ Chondrus crispus $(2 \times 15 \mathrm{~g}$ dry weight each month) } \\
\hline \multicolumn{14}{|c|}{ Family Cytheridae } \\
\hline Cythere lutea & (O.F. Müller, 1785) & 5 & 12 & 13 & 31 & 5 & - & 7 & 21 & 1 & 2 & 1 & 1 \\
\hline \multicolumn{14}{|l|}{ Family Cytherurinae } \\
\hline Hemicytherura cellulosa & (Norman, 1865) & - & - & - & - & - & - & - & - & - & - & - & - \\
\hline Semicytherura nigrescens & (Baird, 1938) & 1 & - & 1 & - & 7 & 2 & - & - & - & - & - & 5 \\
\hline Semicytherura sella & (Sars, 1866) & 1 & - & - & - & - & - & - & - & - & - & 1 & - \\
\hline \multicolumn{14}{|c|}{ Family Hemicytheridae } \\
\hline Heterocythereis albomaculata & (Baird, 1838) & - & - & - & - & 16 & 5 & - & - & 2 & - & 9 & - \\
\hline \multicolumn{14}{|c|}{ Family Loxoconchidae } \\
\hline Hirschmannia viridis & (O.F. Müller, 1785) & - & - & - & - & -. & - & - & 2 & - & - & 1 & 143 \\
\hline Palmoconcha laevata & (Norman, 1865) & 1 & - & - & - & - & - & - & - & - & - & - & - \\
\hline \multicolumn{14}{|l|}{ Family Xestoleberidae } \\
\hline Xestoleberis depressa & Sars, 1866 & 2 & - & - & - & 14 & - & 2 & - & - & - & - & - \\
\hline Xestoleberis aurantia & (Baird, 1838) & - & - & - & - & - & - & - & - & - & - & - & - \\
\hline \multicolumn{14}{|l|}{ Family Paradoxostomatidae } \\
\hline Paradoxostoma abbreviatum & Sars, 1866 & - & - & - & - & - & - & - & - & - & - & - & - \\
\hline Paradoxostoma bradyi & Sars, 1928 & 13 & 5 & 26 & 9 & 4 & - & 2 & 3 & 4 & 2 & 6 & 4 \\
\hline Paradoxostoma ensiforme & Brady, 1868 & - & - & - & - & - & - & - & 2 & - & 2 & - & - \\
\hline Paradoxostoma hibernicum & Brady, 1868 & 5 & 2 & 3 & 13 & 28 & 5 & 7 & 17 & 77 & 44 & 11 & - \\
\hline Paradoxostoma normani & Brady, 1868 & - & - & - & - & - & - & - & - & - & - & - & - \\
\hline Paradoxostoma robinhoodi & Horne \& Whittaker, 1985 & - & - & - & - & - & - & - & 1 & - & - & - & - \\
\hline Paradoxostoma variabile & (Baird, 1835) & - & - & - & - & 4 & 6 & - & 1 & 6 & 3 & - & 71 \\
\hline Cytherois fischeri & (Sars, 1866) & - & - & - & - & - & - & - & - & - & - & - & - \\
\hline \multicolumn{14}{|c|}{ Cladophora rupestris $(2 \times 15 \mathrm{~g}$ dry weight each month) } \\
\hline \multicolumn{14}{|c|}{ Family Cytheridae } \\
\hline Cythere lutea & (O.F. Müller, 1785) & 248 & 26 & 47 & 14 & 24 & 3 & - & - & 9 & - & - & 172 \\
\hline
\end{tabular}


Appendix 1 (continued)

\begin{tabular}{|c|c|c|c|c|c|c|c|c|c|c|c|c|c|}
\hline Species & & Mar & Apr & May & Jun & Jul & Aug & Sep & Oct & Nov & Dec & Jan & Feb \\
\hline \multicolumn{14}{|l|}{ Family Cytherurinae } \\
\hline Hemicytherura cellulosa & (Norman, 1865) & 9 & - & - & - & - & - & 5 & - & 12 & - & 4 & - \\
\hline Semicytherura nigrescens & (Baird, 1938) & 71 & 10 & - & - & 5 & 19 & 33 & 17 & 18 & 3 & - & - \\
\hline Semicytherura sella & (Sars, 1866) & - & - & - & - & 5 & - & - & - & - & - & - & - \\
\hline \multicolumn{14}{|c|}{ Family Hemicytheridae } \\
\hline Heterocythereis albomaculata & (Baird, 1838) & 18 & 26 & 7 & 7 & 36 & 49 & 8 & - & 3 & - & - & 12 \\
\hline \multicolumn{14}{|l|}{ Family Loxoconchidae } \\
\hline Hirschmannia viridis & (O.F. Müller, 1785) & 9 & 58 & 12 & - & 29 & 9 & 3 & - & 3 & 3 & 13 & 3 \\
\hline Palmoconcha laevata & (Norman, 1865) & 2 & - & - & - & - & - & - & - & 1 & - & - & - \\
\hline \multicolumn{14}{|l|}{ Family Xestoleberidae } \\
\hline Xestoleberis depressa & Sars, 1866 & - & - & - & - & - & 43 & - & - & - & - & - & - \\
\hline Xestoleberis aurantia & (Baird, 1838) & - & 3 & 9 & 10 & - & 20 & 62 & - & - & - & - & 6 \\
\hline \multicolumn{14}{|l|}{ Family Paradoxostomatidae } \\
\hline Paradoxostoma abbreviatum & Sars, 1866 & - & - & - & - & $=$ & - & 2 & - & 3 & - & - & - \\
\hline Paradoxostoma bradyl & Sars, 1928 & - & - & - & - & - & - & 5 & - & - & - & - & - \\
\hline Paradoxostoma ensiforme & Brady, 1868 & 44 & 5 & 8 & 2 & 82 & 40 & 108 & 116 & 76 & 103 & 107 & 61 \\
\hline Paradoxostoma hibernicum & Brady, 1868 & - & - & 16 & 2 & - & - & 10 & 3 & 9 & 3 & - & 6 \\
\hline Paradoxostoma normani & Brady, 1868 & 9 & - & - & 12 & 35 & 30 & 5 & 3 & - & 31 & - & 13 \\
\hline Paradoxostoma robinhoodi & Horne \& Whittaker, 1985 & $5-$ & - & - & - & - & - & - & 3 & - & - & - & 2 \\
\hline Paradoxostoma variabile & (Baird, 1835) & 21 & - & - & - & 88 & 90 & 99 & 96 & 106 & 89 & 19 & 26 \\
\hline Cytherois fischeri & (Sars, 1866) & - & 5 & - & - & 12 & - & - & - & - & 6 & - & 7 \\
\hline \multicolumn{14}{|c|}{ Corallina officinalis $(2 \times 30 \mathrm{~g}$ dry weight each month) } \\
\hline \multicolumn{14}{|l|}{ Family Cytheridàe } \\
\hline Cythere lutea & (O.F. Müller, 1785) & 18 & 192 & 12 & 5 & 18 & 2 & 3 & - & 6 & 9 & - & - \\
\hline \multicolumn{14}{|l|}{ Family Cytherurinae } \\
\hline Hemicytherura cellulosa & (Norman, 1865) & - & - & 1 & 1 & - & - & - & - & - & 6 & - & - \\
\hline Semicytherura nigrescens & (Baird, 1938) & 4 & 10 & - & - & 19 & 15 & - & 5 & 1 & - & - & - \\
\hline Semicytherura sella & (Sars, 1866) & - & - & - & - & - & - & - & - & - & - & - & - \\
\hline \multicolumn{14}{|l|}{ Family Hemicytheridae } \\
\hline Heterocythereis albomaculata & (Baird, 1838) & 2 & 2 & 5 & 2 & 16 & 38 & 3 & - & 9 & - & 3 & 17 \\
\hline \multicolumn{14}{|l|}{ Family Loxoconchidae } \\
\hline Hirschmannia viridis & (O.F. Müller, 1785) & 42 & - & 2 & 2 & 12 & 6 & 5 & - & - & 6 & 4 & 11 \\
\hline Palmoconcha laevata & (Norman, 1865) & - & 3 & - & - & - & - & - & - & - & - & - & - \\
\hline \multicolumn{14}{|l|}{ Family Xestoleberidae } \\
\hline Xestoleberis depressa & Sars, 1866 & - & - & - & - & 12 & 37 & - & - & 2 & - & - & - \\
\hline Xestoleberis aurantia & (Baird, 1838) & 10 & - & - & 1 & - & 15 & 22 & - & - & - & - & - \\
\hline \multicolumn{14}{|l|}{ Family Paradoxostomatidae } \\
\hline Paradoxostoma abbreviatum & Sars, 1866 & - & - & - & 1 & - & - & - & - & - & - & - & - \\
\hline Paradoxostoma bradyi & Sars, 1928 & - & - & - & 1 & 19 & - & - & - & - & - & - & - \\
\hline Paradoxostoma ensiforme & Brady, 1868 & 44 & 2 & 4 & 20 & 47 & 36 & 14 & 61 & 48 & 67 & 7 & 3 \\
\hline Paradoxostoma hibernicum & Brady, 1868 & - & - & 8 & - & - & 2 & 8 & - & 1 & 8 & - & - \\
\hline Paradoxostoma normani & Brady, 1868 & 11 & - & - & 3 & 18 & 18 & - & 3 & 3 & 15 & - & 4 \\
\hline Paradoxostoma robinhoodi & Horne \& Whittaker, 1985 & 8 & - & 1 & 9 & 6 & 5 & - & 8 & - & - & 2 & 23 \\
\hline Paradoxostoma variabile & (Baird, 1835) & 97 & 12 & 19 & 59 & 82 & 70 & 187 & 53 & 107 & 25 & 15 & 71 \\
\hline Cytherois fischeri & (Sars, 1866) & - & - & - & - & 3 & - & - & - & - & 6 & - & - \\
\hline
\end{tabular}

\section{LITERATURE CITED}

Athersuch AJ, Horne DJ, Whittaker JE (1989) Marine and brackish water ostracods. Synopses of the British fauna (new series) no. 43. EJ Brill, Avon

Choat $\mathrm{JH}$, Kingett PD (1982) The influence of fish predation on the abundance cycles of an algal turf invertebrate fauna. Oecologia 54:88-95

Clark KR, Warwick RM (1994) Changes in marine communities: an approach to statistical analysis and interpretation. Natural Environmental Research Council, Plymouth

Coleman $J$ (1940) On the faunas inhabiting intertidal seaweeds. J Mar Biol Assoc UK 24:129-183
Coull BC, Wells JBJ (1983) Refuges from fish predation: experiments with phytal meiofauna from the New Zealand rocky intertidal. Ecology 64:1599-1609

Dommasnes A (1969) On the fauna of Corallina officinalis in Western Norway. Sarsia 38:71-86

Elofson $O(1940)$ Notes on the ostracod fauna of Plymouth. J Mar Biol Assoc UK 24:495-504

Fowler J, Cohen L (1990) Practical statistics for field biology. John Wiley \& Sons, Chichester

Gee JM, Warwick RM (1994) Metazoan community structure in relation to the fractal dimensions of marine macroalgae. Mar Ecol Prog Ser 103:141-150

Gibbons MJ (1988) Impact of predation by juvenile Clinus 
superciliosus on phytal meiofauna: are fish important as predators? Mar Ecol Prog Ser 45:13-22

Gunnill FC (1982) Effects of plant size and distribution on the numbers of invertebrate species and individuals inhabiting the brown alga Pelvetia fastugiata. Mar Biol 69: $263-280$

Hagerman L (1966) The macro- and meiofauna associated with Fucus serratus L. with some ecological remarks Ophelia 3:1-43

Hagerman L (1968) The ostracod fauna of Corallina officinalis L. in Western Norway. Sarsia 36:49-54

Hagerman L (1969) Environmental factors affecting Hirshmannia viridis (O.F. Muller) (Ostracoda) in shallow brackish water. Ophelia 7:79-99

Hagerman L (1978) The life-cycle of three species of algalliving ostracods from brackish water. Ophelia 17:231-237

Hicks GFR (1977) Observations on substrate preference of phytal marine harpacticoids (Copepoda). Hydrobiologia $56: 7-9$

Hicks GFR (1980) Structure of phytal harpacticoid copepod assemblages and the influence of habitat complexity and turbidity. J Exp Mar Biol Ecol 44:157-192

Hicks GFR (1985) Meiofauna associated with rocky shore algae. In: Moore PG, Seed R (eds) The ecology of rocky coasts. Hodder and Stoughton, London, p 36-56

Horne DJ (1982) The vertical distribution of phytal ostracods in the intertidal zone at Gore Point, Bristol Channel. J Micropalaeontol 1:71-84

Jarvis SC, Seed R (1996) The meiofauna of Ascophyllum nodosum (L.) Le Jolis: characterisation of the assemblages associated with two common epiphytes. J Exp Mar Biol Ecol 199:249-267

Johnson SC, Scheibling RE (1987) Structure and dynamics of epifaunal assemblages on intertidal macroalgae Ascophyllum nodosum and Fucus vesiculosus in Nova Scotia, Canada. Mar Ecol Prog Ser 37:209-227

Ludwig JA, Reynolds JF (1988) Statistical ecology: a primer

Editorial responsibility: Otto Kinne (Editor),

Oldendorf/Luhe, Germany on methods and computing. John Wiley \& Sons, New York Magurran AE (1989) Ecological diversity and its measurement. Chapman \& Hall, London

Neale JW (1970) The marine fauna and flora of the Isles of Scilly. Crustacea: Ostracoda. J Nat Hist 4:399-411

Preston A, Moore PG (1989) Seasonal cycles of abundance of the flora and fauna associated with Cladophora albida (Huds.) Kütz in rockpools. J Nat Hist 23:983-1002

Trier K (1993) A preliminary study of the brackish and marine Ostracoda of the Pembrokeshire Coast, S.W. Wales. In: McKenzie KG, Jones PJ (eds) Ostracoda in the earth and life sciences. A.A. Balkema, Rotterdam, p 571-581

Trotter D. Webster JM (1983) Distribution and abundance of marine nematodes on the kelp Macrocystis intergrifolia. Mar Biol 78:39-43

Trotter D. Webster JM (1984) Feeding preferences and seasonality of free-living marine nematodes inhabiting the kelp Macrocystis intergrifolia. Mar Ecol Prog Ser 14: 151-157

Underwood AJ (1997) Experiments in ecology: their logical design and interpretation using analysis of variance. Cambridge University Press, New York

Underwood AJ, Petraitis PS (1993) Structure of intertidal assemblages in different locations: how can local processes be compared? In: Rickleffs RE, Schluter D (eds) Species diversity in ecological communities: historical and geographical perspectives. University of Chicago Press, Chicago, p 38-51

Whatley RC, Wall DR (1975) The relationship between Ostracoda and algae in littoral and sublittoral marine environments. In: Swain FM (ed) Biology and palaeobiology of Ostracoda. Bull Am Palaeontol Soc 65:173-203

Williams R (1969) Ecology of the Ostracoda from selected marine intertidal localities on the coast of Anglesey. In: Neale JW (ed) The taxonomy, morphology and ecology of Recent Ostracoda. Oliver \& Boyd, Edinburgh, p 229-327

Submitted: August 26, 1997; Accepted: October 30, 1997 Proofs received from author(s): December 17, 1997 